\title{
KNEE EFFUSION IN YOUNG ADULTS AS AN EARLY SIGN OF DEGENERATIVE ARTHRITIS
}

\author{
BY \\ R. W. PARNELL \\ Institute of Social Medicine, Oxford
}

Three successive undergraduates attending for routine health examination showed signs of a small effusion in the knee joint. This led to the question:

Was such an amount of fluid normal, or was it, as is commonly taught, pathological when sufficient to be demonstrated clinically?

If it was the result of an abnormality, the finding of three successive cases might simply be a rare sequence. Alternatively, the practice of routine examination might bring to light a defect which, though constituting little or no handicap, was nevertheless common. Lastly, if this amount of fluid was in fact normal, its presence would have to be explained by postulating that the quantities present were in the upper part of the normal range of variation, a range which so far as was known had not been studied with precision. Accordingly it was decided to include examination of the knee joint in subsequent routine health examinations until sufficient data became available to form an opinion of the aetiology.

Effusion was demonstrated in 39 of the next 213 young men examined, and in ten of the next 78 women undergraduates. This gives an incidence of $18 \cdot 3$ per cent. in the men and 12.8 per cent. in the women. The discovery of so many effusions came as a surprise to the author and also to others who, hearing of it for the first time, were inclined to doubt the authenticity, or more cautiously to enquire for details, of the method of examination.

\section{Method of Examination}

With the subject lying on a couch, his leg slightly everted and knee extended, pressure is first applied and then maintained over the suprapatellar pouch of the knee joint. The outer side of the knee is next stroked by the examiner's free hand from above downwards, using pressure firm enough to invert the leg in the final stage if necessary. In this way fluid, if present in more than small amounts, is made to flow into and to fill out the sulcus on the inner aspect of the knee behind the medial border of the patella. Once seen, the manner in which the fluid flows into the sulcus, like water into a lax balloon, is unlikely to be confused with a bulge of the infrapatellar pad of fat. One is in fact more likely to miss a moderate effusion, especially in an obese subject, because the medial sulcus is obliterated by effusion before examination starts.

A few cases with a recent history of injury or internal derangement of the knee were excluded from the series. No case with effusion was included where any complaint, local tenderness, or other abnormal sign was found. Radiographs were not taken because in the absence of symptoms there was no indication to draw attention to a condition the cause of which was so uncertain. 


\section{Examination of Possible Causes}

Table I gives the percentage incidence of knee effusion according to possible aetiological factors.

Age.-Among the men higher incidence was found in higher age groups. From $7 \cdot 2$ per cent. at $17-19$ years, it increased to $33 \cdot 4$ per cent. in those over 25 years old, a trend which is statistically significant. In comparing those under 22 years of age with those of 22 or more, the difference in percentage incidence divided by its standard error equals $2 \cdot 74$.

Sex.-Only 78 women were examined. Their average age was $19 \cdot 3 \pm 0 \cdot 13$ years (S.D. 1·1). The percentage with effusion $(12 \cdot 8)$ was lower than in the men, but the average age of the men $(22 \cdot 0 \pm 0 \cdot 19$ years $)$ was higher. Because of the small size of the sample a more detailed analysis was not conducted for the women.

Weight.-Higher incidence was found in men weighing $160 \mathrm{lb}$. or more, compared with those under $160 \mathrm{lb}$. The difference approaches but does not reach the five-per-cent. level of significance $\left(\frac{\text { Difference }}{\text { S.E. Diff. }}=1.64\right)$. Further doubt is cast upon the possible importance of weight as an independent aetiological factor when it is remembered that weight increases with age, and the association of effusion with increasing age has already been shown to be more significant.

Size of Articular Weight-bearing Surface in the Knee.-It is not possible to measure the exact size of the weight-bearing articular surface at a routine health examination, but it is believed that this area correlates positively with the bicondylar measurement of the femur. This was available for 190 of the same undergraduates from a routine anthropometric study which was being conducted by Dr. J. M. Tanner and the author. From Table I it may be seen that the incidence of effusion diminished from $24 \cdot 1$ per cent. in those with small bicondylar measurements to 16.0 per cent. in those with large bones. The trend is not significant, but it is suggestive, especially when it is remembered that differences, if any, due to growth, weight gain, or increasing age, would tend in the opposite direction.

Combination of Weight and Width of Femur.-The incidence was next examined according to combinations of weight and bone size. In a group of 48 with smaller bones and greater weight it was 31.3 per cent., and in another group with larger bones and smaller weight it was only 14.9 per cent. This difference in the percentages with effusion is significant $\left(\frac{\text { Difference }}{\text { S.E. Diff. }}=2.09\right)$ and suggests a mechanical factor leading to greater frequency of effusion where the weight is great and the weightbearing joint surface small. The average age of the two groups was checked, and the difference in the means $(0.4$ years $)$ may be regarded as insignificant since the standard error of the whole sample of 190 was 0.21 years. Further subdivision of the two contrasting combinations (smaller bones with greater weight and larger bones with lower weight) into those under 22 years old and those of 22 years or more is interesting. Table II (overleaf) suggests that, although samples are reduced to a level where staristical significance is lost, that age and the mechanical factor are independent. A difference in incidence of 13.2 per cent. in younger subjects, which might be attributed to the mechanical factor, can be compared with 14.7 per cent. in 
TABLE I

PERCENTAGE INCIDENCE OF KNEE EFFUSION IN YOUNG MEN, BY POSSIBLE CAUSES

\begin{tabular}{|c|c|c|c|c|c|c|}
\hline \multirow{2}{*}{\multicolumn{4}{|c|}{ Possible Causes }} & \multirow{2}{*}{ No. at Risk } & \multicolumn{2}{|c|}{ With Effusion } \\
\hline & & & & & Number & Per cent. \\
\hline Age (yrs) & 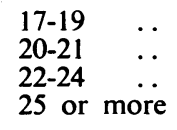 & $\begin{array}{l}. \\
\cdots \\
\cdots \\
\cdots\end{array}$ & $\begin{array}{l}. . \\
\because \\
\cdots \\
.\end{array}$ & $\begin{array}{l}42 \\
71 \\
61 \\
39\end{array}$ & $\begin{array}{r}3 \\
10 \\
13 \\
13\end{array}$ & $\begin{array}{r}7 \cdot 2 \\
14 \cdot 1 \\
21 \cdot 3 \\
33 \cdot 4\end{array}$ \\
\hline Weight (lb.) & $\begin{array}{l}\text { Small: less th } \\
\text { Medium: } 15 \\
\text { Great: } 160\end{array}$ & $\begin{array}{l}\text { han } 150 \\
0 \text { to } 159 \\
\text { or more }\end{array}$ & $\begin{array}{l}\cdots \\
\cdots \\
\cdots\end{array}$ & $\begin{array}{l}83 \\
57 \\
73\end{array}$ & $\begin{array}{r}12 \\
9 \\
. \quad 18\end{array}$ & $\begin{array}{l}14 \cdot 0 \\
15 \cdot 8 \\
24 \cdot 6\end{array}$ \\
\hline \multirow{2}{*}{$\begin{array}{l}\text { Age (yrs) and } \\
\text { Weight (lb.) }\end{array}$} & Under 22 & $\begin{array}{l}\text { less than } \\
\text { more thar }\end{array}$ & $\begin{array}{ll}150 & \ldots \\
\text { in } 150 & \ldots\end{array}$ & $\begin{array}{l}51 \\
62\end{array}$ & $\begin{array}{l}5 \\
8\end{array}$ & $\begin{array}{r}9 \cdot 8 \\
12 \cdot 9\end{array}$ \\
\hline & 22 and over & $\begin{array}{l}\text { less than } \\
\text { more thar }\end{array}$ & $\begin{array}{cc}150 & \\
\text { n } 150 & \ldots\end{array}$ & $\begin{array}{l}32 \\
68\end{array}$ & $\begin{array}{r}7 \\
19\end{array}$ & $\begin{array}{l}21 \cdot 9 \\
28 \cdot 0\end{array}$ \\
\hline $\begin{array}{l}\text { Bicondylar Measurement } \\
\text { of Femur }(\mathrm{cm} .)\end{array}$ & $\begin{array}{l}\text { Small (less th } \\
\text { Medium }(9 \cdot 5 \\
\text { Large }(10 \cdot 0\end{array}$ & $\begin{array}{l}\text { han } 9 \cdot 5 \text { ) } \\
5 \text { to } 9 \cdot 9 \text { ) } \\
\text { or more) }\end{array}$ & $\begin{array}{l}\cdots \\
\cdots \\
\cdots\end{array}$ & $\begin{array}{l}58 \\
89 \\
43\end{array}$ & $\begin{array}{r}14 \\
17 \\
7\end{array}$ & $\begin{array}{l}24 \cdot 1 \\
19 \cdot 1 \\
16 \cdot 3\end{array}$ \\
\hline $\begin{array}{l}\text { Smaller bones and greater } \\
\text { weight }\end{array}$ & $\begin{array}{l}\text { Small bones, } \\
\text { Medium bon }\end{array}$ & $\begin{array}{l}\text { wt. over } \\
\text { hes, wt. ove }\end{array}$ & $\begin{array}{l}150 \mathrm{lb} . . \\
\text { er } 160 \mathrm{lb} .\end{array}$ & 48 & 15 & $31 \cdot 3$ \\
\hline $\begin{array}{l}\text { Larger bones and smaller } \\
\text { weight }\end{array}$ & $\begin{array}{c}\text { Medium and } \\
\text { less than }\end{array}$ & $\begin{array}{l}\text { d large bo } \\
160 \mathrm{lb} .\end{array}$ & $\begin{array}{c}\text { ones, wt. } \\
\ldots \quad \ldots\end{array}$ & 74 & 11 & $14 \cdot 9$ \\
\hline Bones and weight similar & $\begin{array}{l}\text { Small bones, } \\
\text { Medium bon } \\
\text { Large bones, }\end{array}$ & $\begin{array}{l}\text {, small wei } \\
\text { hes, mediun } \\
\text {, great wei }\end{array}$ & $\begin{array}{l}\text { ight } \\
\text { m weight } \\
\text { ight } \quad .\end{array}$ & $\begin{array}{l}39 \\
30 \\
29\end{array}$ & $\begin{array}{l}7 \\
4 \\
5\end{array}$ & $\begin{array}{l}18 \cdot 0 \\
13 \cdot 3 \\
17 \cdot 3\end{array}$ \\
\hline $\begin{array}{l}\text { Physical Constitution } \\
\text { (Sheldon's metric types) }\end{array}$ & $\begin{array}{l}\text { Endomorphs } \\
\text { Mesomorphs } \\
\text { Ectomorphs } \\
\text { Midrange ty }\end{array}$ & $\begin{array}{ll}\text { s } & \ldots \\
\text { s } & \ldots \\
\text { pes } & \ldots\end{array}$ & $\begin{array}{l}\cdots \\
\cdots \\
\cdots \\
\cdots\end{array}$ & $\begin{array}{l}21 \\
74 \\
51 \\
36\end{array}$ & $\begin{array}{r}6 \\
11 \\
13 \\
7\end{array}$ & $\begin{array}{l}28 \cdot 8 \\
14 \cdot 9 \\
25 \cdot 0 \\
19 \cdot 4\end{array}$ \\
\hline Athletic Injury & $\begin{array}{l}\text { Contact spor } \\
\text { Non-contact } \\
\text { Misc. light ex }\end{array}$ & $\begin{array}{l}\text { rts } \ldots \\
\text { t sports } \\
\text { exercise or }\end{array}$ & $\ddot{\text { nil }}$ & $\begin{array}{l}65 \\
91 \\
87\end{array}$ & $\begin{array}{l}13 \\
17 \\
14\end{array}$ & $\begin{array}{l}20 \cdot 0 \\
18 \cdot 7 \\
16 \cdot 1\end{array}$ \\
\hline Socio-Economic Factors & $\begin{array}{l}\text { Ex-boarding } \\
\text { Ex-elementar }\end{array}$ & $\begin{array}{l}\text { school } \\
\text { iry school }\end{array}$ & $\begin{array}{l}\cdots \\
\cdots\end{array}$ & $\begin{array}{l}72 \\
73\end{array}$ & $\begin{array}{l}11 \\
16\end{array}$ & $\begin{array}{l}15 \cdot 0 \\
22 \cdot 0\end{array}$ \\
\hline Total Young & Men Examin & ned & .. & 213 & 39 & $18 \cdot 3$ \\
\hline
\end{tabular}

older subjects. The differences which might be attributed to age in each separate combination of bone size and weight are similar ( 8.3 and 6.8 per cent.). Lastly, there were four subjects with effusion in a small but extreme group of eight whose bicondylar measurements were less than $9 \cdot 5 \mathrm{~cm}$. but whose weight exceeded $160 \mathrm{lb}$.

\section{Other Factors Examined}

Physical Constitution.-Body type had already been determined in this series of young men (using Sheldon's photographic and metric technique), and the data were therefore examined for evidence of constitutional disposition to knee effusion. 
TABLE II

INCIDENCE OF KNEE EFFUSION IN YOUNG MEN, BY AGE, BONE SIZE, AND WEIGHT

\begin{tabular}{|c|c|c|c|}
\hline \multicolumn{2}{|l|}{ Age (years) } & $17-21$ & 22 and over \\
\hline $\begin{array}{l}\text { Small bones, weight over } 150 \mathrm{lb} . \\
\text { Medium bones, weight over } 160 \mathrm{lb} \text {. }\end{array}$ & $\therefore$ & $4 / 16(25 \cdot 0$ per cent. $)$ & $10 / 30(33 \cdot 3$ per cent.) \\
\hline $\left.\begin{array}{l}\text { Medium bones, } \\
\text { Large bones, }\end{array}\right\}$ weight less tha & lb. & $5 / 42(11 \cdot 8$ per cent.) & $6 / 32$ (18.6 per cent.) \\
\hline
\end{tabular}

Exact definitions of the constitutional types have been given by Sheldon and others (1940), but for present purposes it is enough to indicate that endomorphs are usually fat men in middle age, mesomorphs are muscular men with heavy bone structure, and ectomorphs are those men whose weight is small in proportion to their height. Midrange somatotypes are found near the centre of the general distribution of physical types. The lowest incidence of effusion was found in 74 mesomorphs, and the difference in proportion between mesomorphs and other

' types with effusion approaches statistical significance $(\stackrel{\text { Sifference }}{\text { S.E. Diff. }}=1.57)$. The difference could have arisen by chance, though the odds favour it not doing so. On the other hand, two of the characteristics of mesomorphs described by Sheldon are $(a)$ that their bones are broad, and (b) that their body ratio height/cube root of weight is seldom less than $12 \cdot 5$, that is, their weight is seldom so excessive in proportion to their height as it commonly is in fat men. The bones of endomorphs, as of ectomorphs, tend to be slender. Once again the mechanical factor is suggested. Constitutional study does not appear to assist understanding beyond this point.

Sport.-Men playing rugger, soccer, and hockey were grouped together as taking part in contact sports. Rowing men, cross-country runners, and other athletes (including those who cycled for recreation) were grouped as taking part in non-contact sports. The remainder took miscellaneous light exercise or virtually no regular outdoor exercise at all. The slightly higher incidence of effusion (20 per cent.) in those taking part in contact sports is not significant.

Socio-Eçonomic Factors.-An attempt to gauge socio-economic factors was made by dividing the subjects into those whose early circumstances permitted boardingschool education as distinct from Government-aided primary education. The difference of 7 per cent. is not significant.

\section{Discussion}

To summarize findings thus far, two factors show a significant association with effusion in the knee. These are age and a mechanical factor which involves more than average weight being borne by bones of narrow cross section. These findings render it unlikely that the effusions consist of normal synovial fluid. The evidence that repeated injury to athletes is important in the aetiology is negligible and no known infectious process would account for so high a rate of incidence in the sample as a whole. If trauma and infection are both unlikely causes, then degenerative lesions may next be considered. Osteo-arthritis is recognized as 
common in middle and old age, especially in the weight-bearing joints of overweight people. At this time of life medical aid is sought on account of pain or other handicap, and the onset of disability rather than the onset of the degenerative process has received the greater attention. However, Gray (1948) reported the occurrence of chondromalacia patellae in a series of young subjects and discussed the surgical treatment of those already suffering severe or prolonged disability. Øwre (1936) reported degenerative changes in the knee joint found at post mortem in 27 of 32 subjects between 20 and 29 years of age, and Bennett and others (1942) confirmed this observation and the fact that degenerative change increased with each decade. Such changes commonly start even before growth ceases. There is, therefore, clear pathological evidence that degenerative changes occur with great frequency in the knee joint of young adults, and it seems probable that the clinical significance of a small effusion is related to these changes. The sign naturally passes unnoticed by subjects who are otherwise healthy and who unless they complain of knee trouble are not likely to have their knees examined.

\section{Prevention of Osteo-Arthritis of the Knees}

Complete prevention of osteo-arthritis seems no more likely than prevention of the process of ageing. On the other hand, if the clinical sign of a small knee effusion by itself is accepted as an early indication of osteo-arthritis, this may lead to weight supervision, and if necessary to weight reduction or other preventive measures being adopted earlier and with better chance of success. Obesity commonly occurs in association with femurs of small bicondylar measurement and it is here that the risk of effusion is greatest. This agrees with the general clinical impression that in middle age osteo-arthritis is especially common in obese patients.

\section{Summary}

(1) Knee effusion was demonstrated by clinical examination in $18 \cdot 3$ per cent. of 213 young men, and in $12 \cdot 8$ per cent. of 78 young women undergraduates, at consecutive routine health examinations.

(2) Examination of possible causes in the men showed a significant increase in the prevalence of effusion in association with age, but an increase in prevalence in association with weight did not reach the 5 per cent. level of significance.

(3) The weight-bearing surface area in the knee joint was assessed by measurement of the bicondylar width of the femur. In a group of 48 men with smaller bones and greater weight the prevalence of effusion was 31.3 per cent., while in another group with larger bones and smaller weight the prevalence was only 14.9 per cent. This difference is significant and suggests a mechanical factor leading to effusion where weight is great and weight-bearing joint surface small.

(4) Effusion was not associated to a significant degree with contact sports, nor is any known infectious process likely to account for a high rate of prevalence. The possibility of degenerative changes is therefore reviewed. Post-mortem examination shows a majority with degenerative changes in the knee joint before the age of 30 , and the clinical sign of effusion is probably related to these changes. 
(5) The sign naturally passes unnoticed in healthy subjects, but if it were accepted as an early indication of osteo-arthritis, its recognition could lead to weight supervision or other preventive measures being adopted at any earlier stage.

Besides 'my debt, already mentioned, to Dr. J. M. Tanner for certain bicondylar measurements of the femur, I wish to acknowledge the statistical assistance of Mrs. C. C. Standley and Miss S. Wilkinson who checked the analysis.

Bennett, G. A., Waine, H., and Bauer, W. (1942). "Changes in the knee joint at various ages." Commonwealth Fund, New York.

Gray, C. (1948). Brit. med. J., 1, 427.

Øwre, A. (1936). Acta chir. scand., 77, Suppl. 41.

Sheldon, W. H., Stevens, S. S., and Tucker, W. B. (1940). “The Varieties of Human Physique." Harper, New York.

\section{Epanchement dans le Genou chez de Jeunes Adultes comme Signe} Précoce d'Arthrite Dégénérative

RÉSUMÉ

(1) On a constaté un épanchement dans l'articulation de genou chez 18,3 pour cent de 213 jeunes gens, et chez 12,8 pour cent de 78 jeunes étudiantes, au cours d'examens médicaux réguliers.

(2) A l'étude des causes possibles chez les hommes on a trouvé que la fréquence de l'effusion augmentait d'une manière significative avec l'âge, mais comparé au poids elle n'atteignait pas 5 pour cent du chiffre significatif.

(3) La surface portante de l'articulation du genou fut déterminée par la mesure de la largeur bicondylaire du fémur. Pour un groupe de 48 hommes avec des os plus petits et un poids plus grand la fréquence de l'épanchement était de 31,3 pour cent, tandis que pour un groupe avec des os plus grand mais d'un poids moindre la fréquence n'était que de 14,9 pour cent. Cette différence significative fait penser à un facteur mécanique menant à une plus grande fréquence d'épanchement là où le poids est grand et où la surface articulaire portante est petite.

(4) L'épanchement n'était pas associé d'une manière significative à des sports de contact; de même, aucun processus infectieux connu ne semble être responsable de la fréquence aussi élevée. On reconsidère, par conséquent, la possibilité d'altérations dégénératives. A l'autopsie on voit dans la majorité des cas des altérations dégénératives de l'articulation du genou avant l'âge de 30 ans, et il parait probable que le signe clinique de l'épanchement soit apparanté à ces altérations.

(5) Ce signe n'est évidemment pas remarqué chez des sujets sains, mais si on l'acceptait comme une manifestation précoce de l'ostéoarthrite, sa découverte ménerait au contrôle du poids ou à toutes autres mesures préventives, prises en temps utile.

\section{Derrame en la Rodilla en Adultos Jóvenes como Signo Precoz de Artritis Degenerativa}

\section{Sumario}

(1) Exámenes clínicos rutinarios practicados en jóvenes estudiantes demostraron la presencia de derrame en la rodilla en $18 \cdot 3 \%$ de 213 varones y $12 \cdot 8$ de 78 mujeres.

(2) Al estudiar las causas posibles se encontró que la prevalencia del derrame em los varones aumentaba de manera significativa con la edad, pero no en relación al pesø, en cuyo respecto el incremento no alcanzaba la cifra de $5 \%$ de significancia.

(3) La superficie soportando el peso en la articulación de la rodilla fué determinada mediante medición de la distancia bicondilar del femur. En un grupo de 48 varones con huesos pequeños y de mayor peso la prevalencia del derrame fué de $31.3 \%$, mientras que en otro grupo con huesos de mayor tamaño y con menor peso del cuerpo la prevalencia fué de sólo $14.9 \%$. Esta diferencia es significativa y hace pensar en un factor mecánico que conduce a mayor frecuencia del derrame cuando el peso es mayor y la superficie de soporte de la articulación, manor.

(4) El derrame no estaba asociado de una manera significativa con las prácticas deportivas, ni se puede atribuir esta alta prevalencia a proceso infectioso conocido alguno. Se revisa, por lo tanto, la posibilidad de cambios degenerativos. Resultados de autopsia muestran una mayoría con cambios degenerativos en la articulación de la rodilla antes de los 30 años de edad y parece probable que el signo clínico de derrame está relacionado con éstos.

(5) Este signo, naturalmente pasa desapercibido en sujetos saludables, pero de ser aceptado como indicación temprana de ósteo-artritis, su reconocimiento pudiera conducir a control del peso o a la adopción de otras medidas preventivas en temprana oportunidad. 